\title{
“Application of environmental accounting reporting practices and problems regarding the presentation of it in Bangladesh" (A case study on fossil-fuel sector)
}

\author{
Reajmin Sultana
}

Fareast International University

doi: 10.19044/esj.2016.v13n2p348 URL:http://dx.doi.org/10.19044/esj.2016.v13n2p348

\begin{abstract}
Environmental accounting and reporting is an emerging concept in Bangladesh, although many countries in the world, either developed or developing, are already practicing environmental accounting and reporting in their fossil-fuel sector. Fossil energy resources in Bangladesh consist primarily of natural gas. This study deals with what types of data are required \& how these will be presented in environmental accounting. It attempts to portray progress and drawbacks of Petrobangla Companies in respect of environmental accounting practices \& tries to provide suggestions for better reporting practices. As there is a sustainability problem in energy sector, specially fossil-fuel sector of Bangladesh and the situation of pollution of Bangladesh is huge, environmental accounting practice is crying need to solve these types of problem in Bangladesh.
\end{abstract}

Keywords: Emerging, environmental accounting, fossil energy, sustainability problem

\section{Introduction}

Environmental accounting" - sometimes referred to as "green accounting", "resource accounting" or "integrated economic and environmental accounting" - refers to modification of the System of National Accounts to incorporate the use or depletion of natural resources. Environmental accounting takes into consideration all the costs of a product, including the environmental costs of an economic entity. Environmental accounts provide data which highlight both the contribution of natural resources to economic well-being and the costs imposed by pollution or resource degradation. In general, companies publish their annual reports which include a statement of comprehensive income, statement of financial position, and statement of changes in financial positions and the information provided in the foot notes in such reports in money terms. In developed 
countries, a significant number of companies now disclose the impact of their activities on the environment. Environmental costs and their impact on company's profit are disclosed by financial accounting. Environmental reporting will ensure the "Corporate Environmental Stewardship" of the company activities. In Bangladesh, there is `economic valuation, accounting and reporting of these resources and their environmental impacts are very important to ensure sustainable development.

\section{Objective of the study}

A study has been conducted to examine the existing environmental accounting and reporting practice of Petrobangla and its companies to find out-

- Whether the companies of Petrobangla provide in its annual report about environmental information.

- Whether Petrobangla and its companies maintain any provision for environmental liability and environmental cost.

- Whether Petrobangla and its companies maintain any approaches of environmental accounting.

- Whether Petrobangla and its companies classify environmental expenditures as capital expenditure or operating expenditure.

- To recommend the probable solutions to the problem.

\section{Research Methodology}

In order to achieve the specific objective of the study data are collected from both primary and secondary sources.

- Primary Data-The study considered primary data in order to assess the need and awareness of the respondents as to the environmental reporting practices. The primary data relating to the problems involved in Environmental Accounting \& Reporting and suggestion of some measures as to the overcome the problems were also collected. To this end, a total number of 20 general people were interviewed including student, teacher, business person, Environmentalist, responsible environmentalist. To analyze the present practices of Petrobangla regarding Environmental Accounting some of the officers of Petrobangla and its companies were also interviewed. Semi-structured questionnaire was prepared and followed direct interview method to know the relevant information.

- Secondary data-The secondary data are collected from various books, journals, articles, periodical reports, research papers. An initial scrutiny of recent annual reports of Petrobangla \& its companies has been done to observe the incidence of environmental accounting 
reporting. The companies making environmental disclosures were rigorously examined and analyzed.

\section{Literature Review}

Alewine et al. (2010) examined the environmental disclosures of twenty Australian firms subject to a successful EA prosecution between 1994 and 1998 using content analysis, finding the disclosures made by their sample firms to be predominantly positive in nature. Similarly using content analysis, Hecht (1999) found a tendency by their sample firms to disclose higher levels of positive environmental news. Finally, also using content analysis, Kurantin (2011) found that even where a firm has a specific corporate environmental policy, they place a low priority on reporting environmental performance data to external parties. He concluded that firms prefer to disclose their activities and specific programs rather than their research and development, capital expenditure, policies or performance.

Banerjee (2002) employed simultaneous equations approach to investigate the relations among environmental disclosure, environmental performance and economic performance. They used proxy for environmental performance using the percentage of total waste generated recycled as identified using the TRI database and measure environmental disclosure using a content analysis in four categories- potential responsible parties' designation, toxic waste, oil and chemical spills, and environmental fines and penalties.

Lungu et al. (2008) stated that 'Environmental Accounting (EA)' represents a combined approach that provides for the transition of data from financial accounting, cost accounting and mass balances to increase material efficiency, reduce environmental impacts, risks and reduce costs of environmental protection.

A few research studies were conducted on Bangladeshi corporations on 'Corporate Environmental Disclosure (CED)'. Belal (1999) found that 90 percent of the companies studied made some environmental disclosures. Imam (2000) conducted a study on CSR practices and it found that only 22.5 percent on environmental disclosure. Belal (2001) pointed out that CSR practices in Bangladesh is greatly influenced by social, political, cultural, legal, economic and technological factors. He (2001) further added that the creditability of information disclosed is questionable because of absence of independent verification. The reasons for non-disclosure stated by him are lack of statutory requirements, the presence of very few organized social groups and less social awareness, an under-developed corporate culture and relatively new capital market.

Hossain et al. (2006) reported that a very few companies in Bangladesh are making efforts to provide social or environmental 
information on a voluntary basis, which are mostly qualitative in nature. The degree of 'Corporate Social Environmental Disclosure (CSED)' level is the lowest and the significant number of the lowest ranking companies suffered losses during the study period. This study revealed that the nature of the company (Industry), presence of debentures in annual report (Debenture) and net profit margin are mainly related with the significant level of CSED (Hossain, 2006).

Another important issue is pointed out by Rahman and Muttakin (2005) that absence of standard environmental reporting framework. Belal (2007) further stated the problems of non-disclosure on environmental issues such as lack of legal requirements, lack of resources, lack of knowledge, poor performance and bad publicity.

Another study entitled "Environmental Disclosure - A Bangladesh Perspective” conducted by Shil and Iqbal (2005) is also remarkable. The study has reported that EAR practices have not been a widely concept in the related companies so far. The study has also pointed out that environmental disclosure still at initial stage in Bangladesh.

\section{Overview of environmental accounting}

\subsection{Structure of environmental accounts}

All economics are heavily dependent on the environment as a source of materials and energy, as a sink for waste products and as the physical habitat for the human community. The capacity of the environment constitutes our natural capital. Stock and flow of environmental goods are to be recorded in system of national accounts (SNA) as it is supposed by the concerned efforts of United Nations statistics division, the European Union, the World Bank, and the OECD. Through their efforts, they proposed framework and methodologies of environmental accounts. These framework and methodologies certainly provide a set of indicators that can monitor the environmental economic performance at the sartorial level as well as at the macro level. Also they provide guidelines to the resource manager to make important policy decisions. For many organizations, especially in highpolluting industries, environmental issues significantly impact their business performance and financial profitability. Environmental liabilities are financial obligations that companies have to provide for, incur, and disclose, to address environmental concerns.

Environment and natural resource accounts have four components:

1. Natural resource assets accounts, stock of natural resources constructed to revise the balance sheet of the SNA and improve resource management.

2. Pollutant and material (resource and energy) flow accounts, which provide information at the industry level about the use of energy and 
materials as input to production and final demand, and the generation of pollutant and solid waste.

3. Environmental protection and resource management expenditure accounts, which identify expenditure in the conventional SNA incurred by industry, government, and households to protect the environment or manage resources.

4. Environmentally adjusted macroeconomic aggregates, which include indicators of sustainability such as environmentally adjusted net domestic product. (Lange et al. 2003).

\subsection{Specific requirement for environmental disclosure:}

Many jurisdictions have specific requirements for disclosing environmental information. For

Example:

- The material costs of complying with environmental regulations in future years;

- The costs of remediating contaminated sites if a liability is likely to have been incurred and its magnitude can be approximately estimated;

- Other contingent liabilities arising from environmental exposures;

- Involvement as a party to a legal proceeding about an environmental issue, especially with an agency of government; and

- Any known trend or uncertainty involving environmental issues, including pending regulation that would materially affect the company's business

- $\quad$ Present and future costs for products as well as processes redesign.

- $\quad$ Present and future capital expenditures for pollution and control.

- $\quad$ Physical data related to the reduction of toxicity and waste.

- $\quad$ Estimates of future environmental costs and benefits.

- Present and future costs for products as well as processes redesign.

- Present and future capital expenditures for pollution and control.

- Physical data related to the reduction of toxicity and waste.

- Estimates of future environmental costs and benefits.

- Accumulation of current environmental costs from current as well as past activities and products.

\subsection{Environmental Costs \& Benefit}

(1) Pollution prevention costs (for prevention of pollution of atmosphere, water, soil, etc.)

(2) Global environmental protection costs (Prevention of the greenhouse effect, protection of the Ozone layer, etc.) 
(3) Resource circulation costs (Efficient use of resources, reduction of volume of waste, etc.)

(4) Upstream/downstream costs (Green procurement, recycling, etc.)

(5) Administration costs (Environmental education, maintenance of EMS, planting of greenery at factories, etc.)

(6) R\&D costs (Development of environmentally conscious products)

(7) Social activity costs (Support of environmental activities, contributions, etc.)

(8) Environmental remediation costs (Recovery from soil pollution, etc.)

Environmental cost can be formulated as follows:

\begin{tabular}{|l|}
\hline $\begin{array}{l}\text { Environmental protection costs } \\
\text { (Emission treatment and pollution prevention) }\end{array}$ \\
\hline+ Cost of wasted material \\
\hline+ Cost of wasted capital and labor \\
\hline = Total corporate environmental costs \\
\hline
\end{tabular}

Environmental Benefits:

1) Actual benefits (Benefits that can be directly converted into monetary value, such as reduced charges for electricity, water, etc.)

2) Assumed benefits (Benefits concerning reduction in environmental impacts expressed in monetary value).

3) Customer benefits (Reduction of environmental impacts at the usage phase expressed in monetary value)

4) Risk prevention benefits (The extent to which risks are reduced after the investment compared with before the investment is calculated)

\section{Analysis and discussion}

\subsection{Nature of environmental reporting of Petrobangla companies} as follows:

The nature of Environmental Reporting of Petrobangla Companies is

Petrobangla companies have disclosed only qualitative and descriptive information without any attempts at quantification.

Most of the Petrobangla companies only show positive information and there is non-negative information.

The environmental information can only be found either in the chairman's statement or director's report.

Most of the Petrobangla companies only show their environmental issues regarding protection of the environment, pollution control, planting of trees and other matters. They do not show any information regarding waste generation, conservation of energy, water wastage and recycling of waste, noise nuisance and so on. 


\subsection{Environmental disclosure of Petrobangla companies}

Some of the Petrobangla Companies disclose environmental information in the following ways:

- Gas Transmission Company Limited [2012-13]

Proper co-ordination is being maintained with environmental and safety division of Petrobangla for maintaining the national commitment on ecological balance and environmental protection. In line with government decision a significant number of trees were planted in the under implementation project areas and installations of the company for ensuring ecological balance during the financial year 2012-2013. In view of the importance of environmental conservation, a Safety and Environmental section was included in the revised organ gram.

- Jalalabad Gas Transmission \& Distribution System Limited [2012-13]

In pursuance of Government policy and directives to help maintain ecological balance and prevent environmental pollution, the company in coordination with concerned division of Petrobangla undertook tree plantation programs every year in its different establishments. During the year under review, 280 numbers of trees of different species have been planted and existing plants have been properly nursed and well taken care of.

\section{- Sylhet Gas Fields Limited [2012-13]}

With a view to protect the environment in keeping with the national commitment and to create a sense of awareness among the offices and employee, tree plantation programs were undertaken at the Head office, different gas fields and residential areas of the company.

\section{- Bangladesh Gas Fields Company Limited [2012-13]}

Recommendations relevant to company activities which were made in the final report of Environment and Safety Management System [ESMS] project of Petrobangla are being implemented at different fields/installations and departments of the company. Various Programs continue to be undertaken to enhance awareness regarding environmental and Safety aspects of company activities.

- Pashcimanchal Gas Company Limited [2012-13]

Environment, health and safety are integral part of company's operational policy considerations. A massive tree plantation programs has been implemented at PGCL's premises at Baghabari, Nalka and Sadanandapur; this will give the DRS/RMS an environment friendly look. PGCL also has taken necessary measures as per standard code and practice, to ensure safety and security at Town Bordering Station [TBS] and Consumer Metering Station [CMS]. 
- Barapukuria Coal Mining Company Limited [2012-13]

The company management is taking all necessary measures for protection of environment. "Safety Week" was observed jointly by the company and CMC to enhance safety awareness. Water discharged from the mine area is tested regularly to prevent discharge of polluted water. Plantation of trees started since beginning of the project and continued during this year also.

\section{- Maddhapara Granite Mining Company Limited [2012-13]}

The company has taken necessary measures to prevent environmental pollution at project site during implementation period. For this reason, the mine water and the tube well water of officers/staff residential area are being examined regularly. Moreover, various gases that come out from the mine are being measured by using gas analyzer.

\section{Problem analysis}

\subsection{Problems regarding environmental reporting of Petrobangla companies}

Petrobangla, the sole responsible organization in fossil-fuel sector in Bangladesh, has 13 companies operating under its umbrella dealing in gas exploration, production, transmission, distribution, conversion and development, and marketing of coal and hard rock. Some of the companies disclose environmental information in their annual reports while others do not. Over the years activities of Petrobangla has expanded and diversified to a great extent.

Table 1: Environmental Information Disclosed by Petrobangla Companies in their Annual Report:

\begin{tabular}{|l|l|l|l|}
\hline Year & $\begin{array}{l}\text { No. of companies disclosing } \\
\text { Environmental Information }\end{array}$ & $\begin{array}{l}\text { No. of companies not } \\
\text { disclosing Environmental } \\
\text { information }\end{array}$ & $\begin{array}{l}\text { Total no. of } \\
\text { companies }\end{array}$ \\
\hline $2008-2009$ & 5 & 8 & 13 \\
\hline $2009-2010$ & 5 & 8 & 13 \\
\hline $2010-2011$ & 6 & 7 & 13 \\
\hline $2011-2012$ & 7 & 6 & 13 \\
\hline $2012-2013$ & 7 & 6 & 13 \\
\hline
\end{tabular}

In 2008-2009 \& 2009-2010, only $38.46 \%$ of companies under Petrobangla are disclosing environmental information. During 2010-2011 this disclosing rate was $46.15 \%$ and in $2011-2012$ \& 2012-2013, 53.84\% of companies disclosing environmental information. So the rate of disclosing companies is increasing which is a positive sign for Petrobangla as well as for the environment of Bangladesh. 


\subsection{Problems involved in environmental accounting \& reporting practices}

One of the important objectives of the present study has been to identify the major problems involved in disclosing environmental accounting reporting issues in the selected companies. Following problems have been found from analyzing those reports-

- Environmental accountings have no economic value.

- The method of estimating the social value of environmental goods and services are imperfect, often misleading and construers.

- Estimated values for environmental goods quantified or qualified in terms which have no fixed conversion into money.

- On account of unrecorded environmental costs and difficulty in extracting and separating environmental cost the industry data is virally unreliable.

- Social value placed on environmental goods and services are changing so fast that the estimates are likely to be obsolete before they are available for use.

- Lack of accounting standards for environmental accounting inapplicable assumption.

- Environmental accounting is not a legal obligation in most of the cases in Bangladesh.

- Estimated values for environmental goods quantified or qualified in terms which have no fixed conversion into money.

- The problems: 'Insufficient provision regarding environmental reporting in the companies act-1994' and 'Lack of policies and management support regarding environmental reporting practices' are identified as the top most problems of environmental accounting \& reporting.

\section{Findings of the study}

Findings of this study can be divided by two sections. Firstly, from the result of the survey-

- Environmental can be used in the business enterprises of Bangladesh without hampering their main objective of profit making as there is a positive relationship between Environmental Reporting \& profitability.

- The General people of the society are not that much concern about Environmental issues in Bangladesh but the awareness is increasing day by day. 
- If the general investor will be consider not only the profitability of the firms but also the Environmental disclosure of them at the time of investment then the companies will must provide Environmental Information for their own purpose.

Here the survey report can be showed to make these things clear-

Table 2: Survey Report: Respondents: 20 (students-5, Teacher-4, Housewife-5,

Environmentalist-1, Businessman-5)

\begin{tabular}{|l|l|l|l|l|}
\hline $\begin{array}{l}\text { How much you know } \\
\text { about Environmental } \\
\text { Accounting }\end{array}$ & $\begin{array}{l}\text { Do not know } \\
(50 \%)\end{array}$ & $\begin{array}{l}\text { slightly } \\
\text { know } \\
(30 \%)\end{array}$ & $\begin{array}{l}\text { Deep } \\
\text { knowledge } \\
(10 \%)\end{array}$ & $\begin{array}{l}\text { Clear idea } \\
(10 \%)\end{array}$ \\
\hline $\begin{array}{l}\text { Do you think companies } \\
\text { should disclose } \\
\text { information regarding } \\
\text { Environmental issues? }\end{array}$ & $\begin{array}{l}\text { Strongly } \\
\text { Agreed } \\
(80 \%)\end{array}$ & $\begin{array}{l}\text { Agreed } \\
(10 \%)\end{array}$ & $\begin{array}{l}\text { Disagreed } \\
(10 \%)\end{array}$ & $\begin{array}{l}\text { strongly } \\
\text { disagreed } \\
(0 \%)\end{array}$ \\
\hline $\begin{array}{l}\text { Are you satisfied with the } \\
\text { Environmental Reporting } \\
\text { of the companies of } \\
\text { Bangladesh? }\end{array}$ & $\begin{array}{l}\text { Yes } \\
(10 \%)\end{array}$ & $\begin{array}{l}\text { No } \\
(90 \%)\end{array}$ & & \\
\hline $\begin{array}{l}\text { If you will invest in } \\
\text { companies, will you } \\
\text { consider environmental } \\
\text { disclosure of the } \\
\text { companies? }\end{array}$ & $\begin{array}{l}\text { Yes } \\
(20 \%)\end{array}$ & $\begin{array}{l}\text { No } \\
(80 \%)\end{array}$ & & \\
\hline $\begin{array}{l}\text { What types of } \\
\text { Environmental } \\
\text { information you expect } \\
\text { from the companies? }\end{array}$ & $\begin{array}{l}\text { Environment } \\
\text { protection }\end{array}$ & $\begin{array}{l}\text { Social } \\
\text { activity }\end{array}$ & $\begin{array}{l}\text { Waste } \\
\text { management }\end{array}$ & R \& D \\
\hline
\end{tabular}

Secondly, from analyzing different articles and reports-

- Petrobangla and its companies do not maintain any provision for contingent environmental liability.

- Petrobangla and its companies do not classify the expenditure [incurred for the improvement of the environmental performance] capital and operating nature. They treat the whole expenditure as operating expenditure.

- Petrobangla and its companies prepare their accounts according to the traditional accounting system i.e., there is no determination and classification of environmental expenditures.

- Petrobangla and its companies do not show any economic valuation of the reserve of Oil, Gas and Coal resources in their annual report.

- Petrobangla companies disclose only qualitative and descriptive information without any attempts at quantification.

- Most of the Petrobangla companies only show positive environmental information and there is no negative information. 
- The environmental information can only be found either in the Chairman's statement or Director's report.

- Most of the Petrobangla companies only show their environmental issues regarding protection of the environment, pollution control, planting of trees and other matters. They do not show any information regarding waste generation, conservation of energy, water wastage and recycling of waste, noise nuisance and so on.

- Petrobangla companies do not disclose any exact quantitative facts on expenditure incurred and targets set and achieved.

- Petrobangla has developed a computerized accounting system for itself and its companies but there is no item relating to environmental costs, environmental liability, and economic value of Oil, Gas and Coal resources in their software.

- Petrobangla and its companies do not maintain any approaches [either physical or monetary approaches] of environmental accounting.

- Petrobangla has developed the guidelines for "Environment and Safety Practice" for itself and its companies. But no consistency with the guidelines in their annual report has been found.

\section{Recommendation}

The following are the recommendations based on the findings of the study:

- This study indicated that the Petrobangla has already given much effort in the field of environmental protection. However, the current accounting system does not reflect such efforts for its stakeholders. So, Petrobangla should take the initiative showing such activities in their accounts.

- Environmental expenditures incurred by Petrobangla and its companies should be classified into capital expenditures [e.g., purchasing a new recycling machine, tree plantation, soil remediation] and operating expenditures [e.g., annual operating and maintenance cost of the recycling machine, annual operating and maintenance cost of the tree plantation].

- Environmental bodies of Petrobangla should develop a standard to guide the practices of environmental accounting and reporting.

- Research and studies should be encouraged in the field of environmental accounting and reporting. Environmental division of Petrobangla should strictly oversee that the Petrobangla companies maintain their guidelines in reporting the environmental issues in their annual reports. 
- Environmental Accounting and statistics units should be developed for Petrobangla itself and its different companies.

- A Separate account should be opened for environmental expenditures. It will enable measurement and reporting of environmental expenditures and environmental performance of each company as well as the whole sector.

- According to standard no. 69, issued by the Financial Accounting Standards [FAS] Committee in the United States requires a systematic measurement for the net cash flows regarding the proved oil and gas reserves. Such information is required to be published as supplementary information attached to the standard published accounting sheets and data. Petrobangla and its companies should follow this standard.

- Petrobangla and its companies should show the economic value of the reserve of oil, gas and coal resources in their annual report.

- Petrobangla and its companies should maintain both physical and monetary approaches of environmental accounting.

- Petrobangla and its companies should use the earlier suggested balance sheet to show the present condition of oil, natural gas and coal recourses.

- Petrobangla and its companies should use the earlier suggested environmental management indicators to ensure the viability of their environmental management.

- Petrobangla should maintain the provision for environmental liability.

- Petrobangla and its companies should show data on environmental expenditure, environmental costs charged to income in the notes to the accounts in their annual reports.

- Petrobangla and its companies should show fines and penalties paid by the company, environmental liabilities of the company, environmental provisions, and environmental costs capitalized in the notes to the accounts in their annual reports.

\section{Conclusion}

The practices of environmental accounting in Bangladesh are still at an initial stage. Environmental accounts provide data which highlight both the contribution of natural resources to economic well-being and the costs imposed by pollution. The information provided by the environmental accounting, those concerning the environmental costs can help the managerial team (board) in substantiating the decisions connected to the product design, production process, waste management, investments and so 
on. The information given by the environmental accounting, the analysis of the relation established between the costs and the benefits help the managers of economic entities to base the decisions made concerning environment and its protection, to take actions in order to prevent the environmental damage and to help to evaluate the environmental costs. In response to that concern, many leading organizations of the world are taking initiatives to ensure sustainable development. In the present situation, it is necessary for Petrobangla and its companies to practice environmental accounting to comply with the international trend.

\section{References:}

1. Ahmad, A. (2012). Environmenta Accounting \& Reporting practices:significance and issues(a case from Bangladeshi companies). global journal of management \& business research , XII.

2. Alewine, H. C., \& Stone, D. N. (2010). How Does Environmental Accounting Information Influence Attention and Investment?

3. Banerjee, S. (2002) "Corporate Environmentalism, the Construct and Its Measurement”, Journal of Business Research, V, 177-191.

4. Belal, A. R. (2001). A Study of Corporate Social Disclosures in Bangladesh. Managerial Auditing Journal, , XVI (5), 24-289.

5. Hecht, J. E. (1999). Environmental Accounting: Where we are now \& Where we are heading.

6. Hossain, M., Islam, K. and Andrew, J. (2006). "Corporate Social and Environmental Disclosure in Developing Countries: Evidence from Bangladesh.” Conference paper at Asian Pacific Conference on International Accounting Issues.

7. Imam, S. (1999). “Environmental Reporting in Bangladesh.” Social and Environmental Accounting, VOL XIV(2)

8. Kurantin, D. N. (2011). Integrating Environmental Accounting into Ghana's Emerging Oil and. International Conference on Petroleum and Sustainable Development , XXVI, 66-77.

9. Lungu, C. I., Caraiani, C., \& Guse, R. G. (2008). Corporate Social and Environmental Reporting: Another Dimension for Accounting Information.

10. Rahman, A. (1998). Application of Environmental Accounting in Bangladesh. Journal of International Affairs , IV(1), 48-70.

11. Rahman, N. A. (2012). Sustainable Energy Development: Bangladeshi Perspectives.

12. Shil, N. C., \& Iqbal, M. (2005). Environmental disclosure - a Bangladesh perspectives. Munich Personal RePEc Archive . 
13. Bangladesh Oil, Gas and Mineral Corporation (Petrobangla) Annual Report 2008-09,2009-2010,2010-2011,2011-2012,2012-13, Petro center, 3, Karwan Bazar, Dhaka.

14. Financial Accounting Standards Board, "Statement of Financial Accounting Standards No. 69 -Disclosure about Oil and Gas Producing Activities,”

\section{Appendices}

\section{Questionnaire for general people:}

"Application of environmental accounting reporting practices and problems regarding the presentation of it in Bangladesh"

Name:

Age:

Profession:

Questionnaire:

1. How much you know about Environmental Accounting?

- a) Do not know

b) slightly know

- c) Deep knowledge

d) clear idea

2. As an active citizen of society do you think companies should disclose information regarding Environmental issues?

$\begin{array}{ll}\text { a) Strongly Agreed } & \text { b) Agreed }\end{array}$

c) Disagreed

d) strongly disagreed

3. Are you satisfied with the Environmental Reporting of the companies of Bangladesh?

- a) Strongly Agreed

- c) Disagreed

b) Agreed

d) strongly disagreed

4. If you will invest in companies, will you consider environmental disclosure of the companies?
a) Yes
b) No

5. What types of Environmental information you expect from the companies?

Questionnaire: For concerned person of Petrobangla \& its companies

1. Do you think Environmental Accounting is significant for the business enterprises of Bangladesh?

2. Do you think Environmental Accounting should be implemented in fossil fuel sector of Bangladesh? Why or why not?

3. What are the existing environmental accounting and reporting practices of Petrobangla?

4. What are the steps taken by Petrobangla to implement Environmental protection?

5. Do the companies under Petrobangla disclose information related to Environmental Accounting?

6. What are the problems Petrobangla have to face for the implementation of Environmental Accounting?

7. Do you think Government should take initiative for the betterment of practice of Environmental Accounting? What are those? 